\title{
Spring molybdenum enrichment in scallop shells: a potential tracer of diatom productivity in temperate coastal environments (Brittany, NW France)
}

\author{
A. Barats ${ }^{1, *}$, D. Amouroux ${ }^{1}$, C. Pécheyran ${ }^{1}$, L. Chauvaud ${ }^{2}$, J. Thébault ${ }^{2}$, and O. F. X. Donard ${ }^{1}$ \\ ${ }^{1}$ Laboratoire de Chimie Analytique Bio-Inorganique et Environnement (LCABIE) - Institut Pluridisciplinaire de Recherche \\ sur l'Environnement et les Matériaux (IPREM), UMR 5254 CNRS - Université de Pau et des Pays de l'Adour (UPPA), \\ Hélioparc Pau-Pyrénées, 2 av. du Président Angot, 64053 Pau Cedex 9, France \\ ${ }^{2}$ Laboratoire des sciences de l'Environnement MARin (LEMAR) - Institut Universitaire Européen de la Mer (IUEM), UMR \\ 6539 CNRS - Université de Bretagne Occidentale (UBO), Technopole Brest-Iroise, Place Nicolas Copernic, \\ 29280 Plouzané, France \\ *now at: Laboratoire de Radiochimie et des Sciences Analytiques et Environnement (LRSAE/EA 1175) - Institut de Chimie \\ de Nice (FR CNRS 3037) - Université de Nice Sophia Antipolis (UNSA), 28 avenue Valrose, 06108 Nice Cedex 2, France
}

Received: 16 July 2009 - Published in Biogeosciences Discuss.: 6 August 2009

Revised: 18 December 2009 - Accepted: 6 January 2010 - Published: 19 January 2010

\begin{abstract}
Skeletal molybdenum/calcium ([Mo]/[Ca $)_{\text {shell }}$ ratios were examined in shells of the Great Scallop Pecten maximus collected in temperate coastal environments of Western Europe ( 42 to $\left.49^{\circ} \mathrm{N}\right)$. These ratios were determined by quantitative LA-ICP-MS analyses of daily striae taken every third day (i.e. a temporal resolution of 3 days) in 36 flat valves (2years old; 3 shells/year). Variations of ([Mo]/[Ca] $)_{\text {shell }}$ ratios were significant and reproducible for scallops from the same population, from different years (1998-2004) and temperate coastal locations (NW France). The $[\mathrm{Mo}] /[\mathrm{Ca}])_{\text {shell }}$ ratios exhibit typical profiles characterized by a background content, below the detection limit for this method $(<0.003 \mu \mathrm{mol} / \mathrm{mol})$ for most of the shell growth period, which is punctuated by a significant transient enrichment $(0.031-2.1 \mu \mathrm{mol} / \mathrm{mol})$ mainly occurring from May to June. The Bay of Brest (France) was investigated in particular because of its long term observations on scallop communities, environmental variables, and high resolution analyses of dissolved Mo in bottom seawater in 2000. In 2000, dissolved Mo exhibited a significant increase in concentration just preceding the maximum $([\mathrm{Mo}] /[\mathrm{Ca}])_{\text {shell }}$ ratio. Both the intense monitoring survey in 2000 and over the 7-year period indicates that the $([\mathrm{Mo}] /[\mathrm{Ca}])_{\text {shell }}$ maximum is directly influenced by spring changes of environmental conditions at the sediment water
\end{abstract}

Correspondence to: D. Amouroux (david.amouroux@univ-pau.fr) interface (SWI), occurring subsequent to the intense and periodic spring bloom. Spring maxima of $([\mathrm{Mo}] /[\mathrm{Ca}])_{\text {shell }}$ ratios are closely correlated to the extent of silicic acid and nitrate depletion in seawater between winter and late spring $\left(r^{2}=0.878\right.$ and $\left.0.780, p<0.05, n=6\right)$ that reflects diatom uptake and productivity in the Bay of Brest. The Mo inputs in bottom waters and subsequent shell enrichment are thus suggested to be directly or indirectly influenced by such biogenic material input at the SWI. The $[\mathrm{Mo}] /[\mathrm{Ca}])_{\text {shell }}$ records thus reveal unexpected biogeochemical cycles of Mo influenced by coastal spring productivity, faithfully recorded in scallop shells.

\section{Introduction}

Mollusc bivalves grow through an incremental deposition of calcium carbonate $\left(\mathrm{CaCO}_{3}\right)$ layers with most species exhibiting specific temporal marking in shell composition (Stecher et al., 1996; Chauvaud et al., 1998, 2005). Bivalves can preserve, within their own exoskeleton, a chronological record of the environmental variations they have experienced during their life. Following this growth pattern, several investigations have demonstrated that variations of the historical elemental composition along the shell growth axis can be used as proxies for coastal biogeochemical processes (Dodd, 1965; Lorens and Bender, 1980; Klein et al., 1996a, b). For

Published by Copernicus Publications on behalf of the European Geosciences Union. 
most of the species (Mercenaria mercenaria, Mytilus edulis, Isognomon ephippium, Ensis siliqua), trace element profiles within the shell, provide chronological records of environmental conditions experienced by the bivalves (Puente et al., 1996; Stecher et al., 1996; Giusti et al., 1999; Vander Putten et al., 2000; Richardson et al., 2001; Lazareth et al., 2003; Gillikin et al., 2005). In these studies, an approximate date of formation has often been assigned to the shell deposit to interpret historical information. Different methods such as shell sclerochronology or oxygen stable isotope composition have demonstrated that the Great Scallop Pecten maximus (L.) develops the specific feature to precipitate a distinct daily stria of $\mathrm{CaCO}_{3}$ on its shell (Chauvaud et al., 1998, 2005). This scallop has been promoted as a good candidate for environmental proxy calibration on a daily scale (Chauvaud et al., 1998, 2005; Lorrain et al., 2000, 2005; Barats, 2006; Barats et al., 2008, 2009). This bivalve grows in coastal environments over a wide range of latitudes $\left(30^{\circ}\right.$ to $\left.60^{\circ} \mathrm{N}\right)$ and bathymetry (1 to $\left.500 \mathrm{~m}\right)$. At temperate latitudes such as in France (Brittany), the scallop shell exhibits (i) a fast daily growth rate (maximum $350 \mu \mathrm{m}$ per day) and (ii) an extended growth period, approximately from April to November, during the second year of growth (Chauvaud, 1998; Chauvaud et al., 2005). The shell growth rate is influenced by seawater temperature (scallop grows only if $T_{\mathrm{sw}}>9-10^{\circ} \mathrm{C}$ ), and limited by massive or toxic phytoplankton blooms (Lorrain et al., 2000; Owen et al., 2002a, b). P. maximus is a non-selective filter feeder ingesting both dissolved and particulate material within the bottom waters surrounding the scallop (Chauvaud, 1998; Chauvaud et al., 1998, 2005; Lorrain et al., 2005). The variations of trace element shell concentrations provide significant and highly detailed historical information (Freitas et al., 2005, 2006; Lorrain et al., 2005; Barats, 2006; Barats et al., 2007, 2008). For example, manganese (Mn) concentrations along the shell were recently demonstrated to be mainly governed by concentrations of dissolved Mn at the SWI (sediment water interface) being themselves controlled by freshwater inputs and benthic release (Freitas et al., 2006; Barats et al., 2008). More recently, $([\mathrm{Ba}] /[\mathrm{Ca}])_{\text {shell }}$ and $([\mathrm{Mo}] /[\mathrm{Ca}])_{\text {shell }}$ ratios were examined in Pectinidae because their variations highlighted intriguing profiles with a sharp annual increase during the spring (Barats et al., 2007, 2009; Gillikin et al., 2008; Thébault et al., 2009).

Molybdenum (Mo) is one of the most abundant transition group metals in seawater, mainly present as the oxy anion $\mathrm{MoO}_{4}^{2-}$ in oxygenated environment (Collier, 1985). Mo is generally considered to be conservative in pelagic waters with a concentration averaging $110 \mathrm{nmol} / \mathrm{L}$ in seawater, suggesting little influence of biogeochemical processes on its concentration (Collier, 1985). Coastal Mo distribution is also influenced by freshwater-seawater mixing (Dalai et al., 2005). Some studies however, highlight that Mo can also present non-conservative behaviour in coastal waters, both at the SWI (Adelson et al., 2001; Chaillou et al., 2002; Cru- sius et al., 1996; Elbaz-Poulichet et al., 2005), and in the water column (Tuit and Ravizza, 2003; Dellwig et al., 2007). Mo benthic inputs to the SWI can be induced under suboxic conditions via the reduction of sedimentary manganese oxides leading to Mo release in the overlying water as the dissolved compound, $\mathrm{MoO}_{4}^{2-}$ (Crusius et al., 1996; Crusius and Thomson, 2000; Morford et al., 2001; Chaillou et al., 2002; Dalai et al., 2005; Elbaz-Poulichet et al., 2005; Morford et al., 2005). Mo released at the SWI may then diffuse back into the water column or can be authigenically reprecipitated into Mo-Fe-S forms under strict anaerobic conditions (Erickson and Heltz, 2000; Sundby et al., 2004; Tribovillard et al., 2004; Zheng et al., 2000). In the water column, Mo assimilation by diazotrophic cyanobacteria and phytoplankton is an essential catalytic factor for the majority of $\mathrm{N}_{2}$ fixing organisms and many nitrate reductase systems (Collier, 1985; Hille, 2002). Mo availability may act to limit $\mathrm{N}$ fixation in marine ecosystems, and consequently, may limit primary productivity (Marino et al., 1990; Cole et al., 1993). Various marine phytoplankton species were investigated for their cellular Mo contents, which were reported to be low and homogeneous $(3.3 \mathrm{mmol} \mathrm{Mo} / \mathrm{mol}$ of $\mathrm{P}$, or $3.1 \mu \mathrm{mol} / \mathrm{L}$ of cellular volume) among the 15 phytoplankton species investigated (diatoms, green algae, coccolithophores) (Ho et al., 2003). This concentration obtained under identical culture conditions was apparently independent of the phytoplankton species and did not exhibit any specific assimilation related to the phylogenetic origin of the investigated species, in contrast to other micronutrients (Ho et al., 2003; Quigg et al., 2003). Mo content in marine phytoplankton can however be enriched due to different irradiance conditions (Finkel et al., 2006). Recently, non-conservative behaviour of Mo was revealed in the water column of a coastal environment (Wadden Sea, Germany) (Dellwig et al., 2007). In summer, Mo was demonstrated to be enriched in suspended particulate matter and depleted in the dissolved phase of the seawater. The bacterial decomposition of phytoplankton was reported to promote the release of organic compounds and the formation of Mo-enriched aggregates which may thus settle to the SWI to be rapidly decomposed by microbial activity contributing to a substantial release of Mo in bottom waters (Dellwig et al., 2007).

Through the observation of $([\mathrm{Mo}] /[\mathrm{Ca}])_{\text {shell }}$ ratios along the daily striae of $P$. maximus, the objectives of this study are first, to evaluate $([\mathrm{Mo}] /[\mathrm{Ca}])_{\text {shell }}$ profiles as a potential record of specific biogeochemical processes occurring at the SWI, and second to provide new confirmation of the non-conservative behaviour of Mo in coastal waters. The quantitative micro-analysis of shell Mo content was previously developed using Laser Ablation - Inductively Coupled Plasma - Mass Spectrometry (LA-ICP-MS) and matrixmatched standards (Barats et al., 2007). Quantitative chronological profiles were defined with an accurate date and concentration assignment for each measured striae. A first evaluation of $([\mathrm{Mo}] /[\mathrm{Ca}])_{\text {shell }}$ profiles were performed in different 
scallop populations and years to highlight the reproducibility, ubiquity and periodicity of the $([\mathrm{Mo}] /[\mathrm{Ca}])_{\text {shell }}$ maxima. These maxima were then examined over a 7-year period and particularly in 2000, according to the bivalve physiology and ecological constraints. Finally the main biogeochemical processes influencing the occurrence and the extent of $([\mathrm{Mo}] /[\mathrm{Ca}])_{\text {shell }}$ maxima are discussed.

\section{Materials and methods}

\subsection{Studied site and scallop sampling}

Three live juvenile specimens of P. maximus were collected each year at the study site in the Bay of Brest, Roscanvel station ( $n=3$ shells per year, 1998-2004, except in 2002: $n=2)$, off Belle Ile in $1999(n=3), 2000(n=4)$ and 2001 $(n=3)$, off Quiberon in $2000(n=3)$ and in the Bay of Seine in $2004(n=3)$. Scallops were collected in the late autumn by SCUBA diving in Roscanvel and by dredging at the other sites (NW France). Details concerning sampling sites have been previously reported (Barats et al., 2009). Only the upper valve of the shell was considered (Barats et al., 2007, 2009). Shells were cleaned by soaking in $90 \%$ acetic acid for $45-60 \mathrm{~s}$ to remove bio-fouling, rinsed with distilled water, and air-dried. A $45 \times 10 \mathrm{~mm}$ cross section corresponding to the second year of growth (juvenile stage) was cut along the axis of maximum growth rate (Chauvaud, 1998; Chauvaud et al., 1998). A precleaning ablation of the calcite surface was carried out before LA-ICPMS analyses to avoid surface contamination. This precleaning step consisted of a quick (approximately $20 \mathrm{~s}$ ) pre-ablation of the sample shell stria surface at a rate of $50 \mu \mathrm{m} / \mathrm{s}$ (Barats et al., 2007).

\subsection{Determination of trace element concentrations in shells}

Quantitative analyses of trace elements within shells were performed by LA-ICP-MS consisting of coupling a UV laser ablation unit (LSX $100 \mathrm{UV} 266 \mathrm{~nm}$, Cetac Tech.) to an ICPMS (X7 series, Thermo Fisher). The methodological approach and analytical performances have been described in detail elsewhere (Barats et al., 2007, 2008, 2009). Briefly, a matrix-matched external calibration was performed with lab prepared $\mathrm{CaCO}_{3}$ pellets. The Mo calibration curve displayed good linearity with a regression coefficient above 0.99 . The detection limit was approximately $27 \mathrm{nmol} / \mathrm{g}$, and the relative standard deviations obtained for both analytical repeatability and reproducibility were below $7 \%$. The $([\mathrm{Mo}] /[\mathrm{Ca}])_{\text {shell }}$ ratios were calculated dividing shell Mo concentrations by the calcium concentration in the shell $(400 \mathrm{mg} / \mathrm{g})$, and expressed in units of $\mu \mathrm{mol} / \mathrm{mol}$ (Barats et al., 2007, 2008, 2009). Shell Ca concentration was assumed to be constant all along the shell surface. Richard (2009) recently investigated the spatial variability of the $\mathrm{Ca}$ concentration in the same collection of juvenile scallop shells intercomparing two independent analytical methods. High resolution ICPMS ( $n>30$, mass spectrometry) and Electron micro-probe ( $n=3$, X-ray electronic spectroscopy) analysis demonstrated that $\mathrm{Ca}$ content was respectively $41.1 \pm 3.1 \%$ and $39.1 \pm 1 \%$, within the same stria or along growth section of the shell surface. Shell analyses were performed each third stria to obtain a temporal resolution of 3 days. A date of formation was assigned to each ablated sample by backdating from the harvest date and based on the daily periodicity of stria formation in $P$. maximus. Chronological profiles of trace elements were then established based on the stria specific date assignment. The uncertainty of the chronological time-scale of mean shell profiles was estimated to be \pm 3 days. An evaluation of the shell growth rate was carried out using an image analysis technique previously described (Chauvaud, 1998).

\subsection{Environmental monitoring}

In order to relate $([\mathrm{Mo}] /[\mathrm{Ca}])_{\text {shell }}$ time-series to environmental parameters and hence to the Mo biogeochemical cycle at the SWI, an intensive environmental survey was conducted in the Bay of Brest, at Roscanvel $\left(48^{\circ} 20^{\prime} \mathrm{N} 4^{\circ} 30^{\prime} \mathrm{W}\right)$, where scallop shells were sampled from 1998 to 2004. Weekly Chlorophyll $a(\mathrm{Chl} a)$ data originated from measurements at the SOMLIT station (Service d'Observation en Milieu LITtoral: $48^{\circ} 22^{\prime} \mathrm{N}, 4^{\circ} 33^{\prime} \mathrm{W}$ ), as part of the monitoring activities of the Intitut Universitaire Européen de la Mer (http://www. univ-brest.fr/IUEM/observation/observation_iroise.htm). A weekly database of seawater nutrient and phytoplankton species also originated from the SOMLIT station. Description of this complete database and a map of the different sites were previously reported (Barats et al., 2009). A specific survey (2-3 days resolution) was also performed at Roscanvel in 2000 (from February to December). Bottom waters were regularly sampled (every 2-3 days) by a diver-operated Niskin sampler positioned and closed horizontally at $1 \mathrm{~m}$ above the SWI to avoid any disturbance the SWI and thus to preserve the characteristic of the bottom water column. After collection, the samples were filtered $(<0.6 \mu \mathrm{m}$, Nucleopore $)$ and acidified in $2 \% \mathrm{HNO}_{3}$ (69-70\% Suprapur, Merck). Before analysis, they were diluted 50 times with Milli-Q water (Millipore). Two internal standards were also added ( $\mathrm{Y}$ and $\mathrm{Bi}$ ) to the diluted samples. Dissolved concentrations of Mo were then determined by ICP-MS (X7 series, Thermo Fisher) by external and internal standard calibration.

\subsection{Statistical analyses}

Statistical data treatment was performed to highlight environmental parameters that can vary with the change of $([\mathrm{Mo}] /[\mathrm{Ca}])_{\text {shell }}$ maximum levels. Most $([\mathrm{Mo}] /[\mathrm{Ca}])_{\text {shell }}$ maxima could be defined using approximately 10 sampling points along the shell (1 point every 3 days), corresponding to a duration of one month (30 days). The most intense section 
of $([\mathrm{Mo}] /[\mathrm{Ca}])_{\text {shell }}$ maxima was generally characterised by a period of 15 to 21 days (i.e., 5 to 7 sampling points) whatever the year. We thus decided to choose integration periods of 2 weeks around the maximum of $([\mathrm{Mo}] /[\mathrm{Ca}])_{\text {shell }}$ ratio, which was consistent with the lower resolution obtained for most environmental parameters and the uncertainty due to the backdating of shell striae. These integration periods took into account an eventual lag between changes in the water column, at the SWI, and its later transcription within the shell. The data integration approach is thus similar to the one used to investigate $([\mathrm{Ba}] /[\mathrm{Ca}])_{\text {shell }}$ maxima (Barats et al., $2009)$, and allowed a good overlapping of $([\mathrm{Mo}] /[\mathrm{Ca}])_{\text {shell }}$ maxima and environmental datasets. To understand the influence of transient events on the intensity of $([\mathrm{Mo}] /[\mathrm{Ca}])$ shell maxima during the trial period, the maximum value of each environmental parameter was also taken for statistical analysis. Bravais Pearson tests and multiple regression analyses were performed with Stabox Pro software for Windows Ver. 6 (Grimmer Software, France). Bravais Pearson tests were used to highlight univariate correlations between the amplitude of $([\mathrm{Mo}] /[\mathrm{Ca}])_{\text {shell }}$ maxima and others variables. Multiple regression analyses were considered to express the amplitude of $([\mathrm{Mo}] /[\mathrm{Ca}])_{\text {shell }}$ maxima related to several independent factors.

\section{Results and discussion}

\subsection{Characterization of $([\mathrm{Mo}] /[\mathrm{Ca}])_{\text {shell }}$ profiles and specific enrichment}

\subsubsection{Reproducibility of $([\mathrm{Mo}] /[\mathrm{Ca}])_{\text {shell }}$ profiles in a same scallop population from the Bay of Brest (Brittany, France)}

The juvenile shell (second year of growth in 2003) of three scallops from the Bay of Brest (Roscanvel) were examined (Fig. 1a). The $([\mathrm{Mo}] /[\mathrm{Ca}])_{\text {shell }}$ concentration ratios showed a similar profile with average background concentrations below the detection limit $(<2.7 \mathrm{nmol} / \mathrm{mol})$, and 5 significant enrichments from May to October (Fig. 1a). A comparison of these Mo profiles among the 3 individual scallop shells reveals significant correlations $\left(r^{2}>0.73, p<0.05, n>60\right.$; Table 1). This result underlines statistically a high reproducibility of $([\mathrm{Mo}] /[\mathrm{Ca}])_{\text {shell }}$ profiles among a same scallop population. As a consequence, an averaged $([\mathrm{Mo}] /[\mathrm{Ca}])_{\text {shell }}$ profile, defined as a mean of 3 shell profiles, can be established and also shows significant spring and summer enrichments (Fig. 1b; Table 1).

Analyses of a three-year-old scallop from the same population were performed from its third year of shell growth during 2003 (Fig. 1b). Comparison of the average juvenile $([\mathrm{Mo}] /[\mathrm{Ca}])_{\text {shell }}$ profile with a three-year-old scallop revealed similar variations. Background $([\mathrm{Mo}] /[\mathrm{Ca}])_{\text {shell }}$ concentrations always remained below the detection limit, and max-
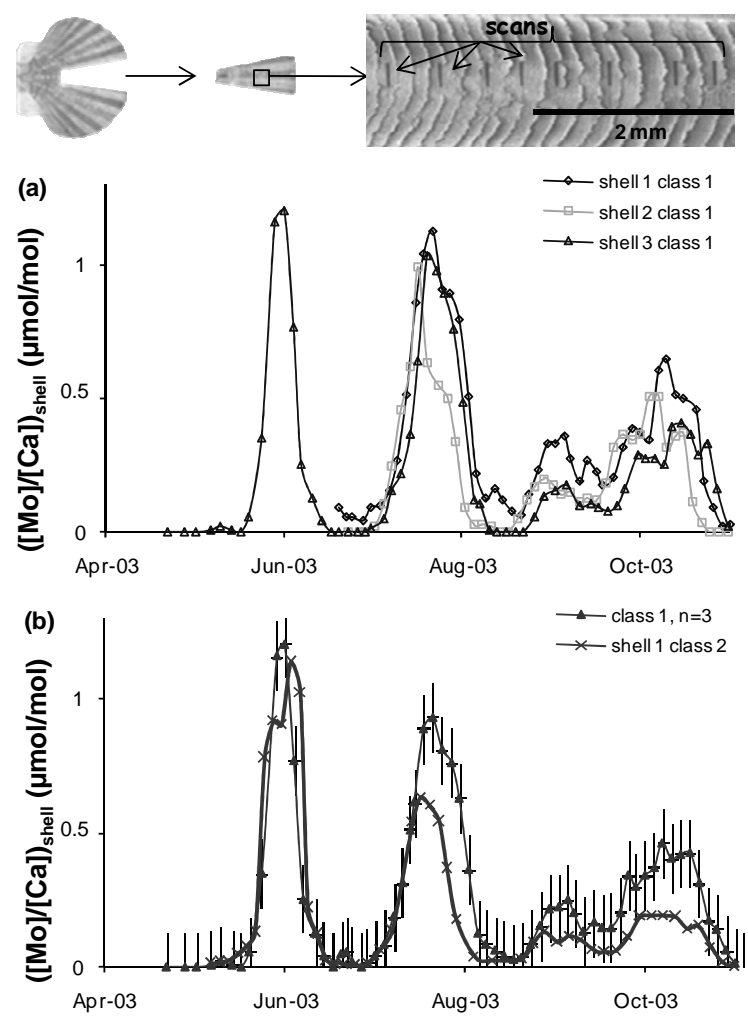

Fig. 1. Comparison of $([\mathrm{Mo}] /[\mathrm{Ca}])_{\text {shell }}$ concentration profiles along the shell section obtained for (a) three juvenile scallop shells (class 1$)$; (b) the mean $([\mathrm{Mo}] /[\mathrm{Ca}])_{\text {shell }}$ concentrations of 3 juvenile shells with standard deviations as error bars and one 3-years old scallop shell (class 2), collected in the Bay of Brest (Roscanvel), in 2003 , to evaluate the inter shell reproducibility of $([\mathrm{Mo}] /[\mathrm{Ca}])_{\text {shell }}$ variations.

ima in $([\mathrm{Mo}] /[\mathrm{Ca}])_{\text {shell }}$ ratios occurred simultaneously in all shell samples during spring or summer. These results establish that: (1) $([\mathrm{Mo}] /[\mathrm{Ca}])_{\text {shell }}$ ratios present an important enrichment in spring or summer, significantly reproducible among a single scallop population; $(2)$ these $([\mathrm{Mo}] /[\mathrm{Ca}])_{\text {shell }}$ maxima do not show any relation to specific physiological or biological factors related to the scallop age.

\subsubsection{Ubiquitous occurrence of $([\mathrm{Mo}] /[\mathrm{Ca}])_{\text {shell }}$ maxima in several scallop populations from temperate coastal environments}

The comparison of $([\mathrm{Mo}] /[\mathrm{Ca}])_{\text {shell }}$ profiles from 1998 to 2001 in 3 different sites is displayed in Fig. 2a. This representation highlights good reproducibility of these shell profiles both for the intra- and inter-annual variations. Examination of $([\mathrm{Mo}] /[\mathrm{Ca}])_{\text {shell }}$ profiles in the different locations studied on the Atlantic coast (NW France) reveals a general pattern with similar background concentrations below the detection limit and significant maxima of $([\mathrm{Mo}] /[\mathrm{Ca}])_{\text {shell }}$ ratio occurring in spring or summer (Table 2). The amplitude of 
Table 1. Intershell comparison of $([\mathrm{Mo}] /[\mathrm{Ca}])_{\text {shell }}$ ratio profiles archived in Pecten maximus shells from a same population (Bay of Brest, Roscanvel station) over a 7-year period (1998-2004) and presentation of ([Mo]/[Ca] $)_{\text {shell }}$ peaks (named in chronological order) observed for each year. The maximum of $([\mathrm{Mo}] /[\mathrm{Ca}])_{\text {shell }}$ ratios and the date of this maximum were averages from 3 shells (except 2002 and 2004).

\begin{tabular}{|c|c|c|c|c|c|c|c|c|}
\hline \multirow{3}{*}{$\begin{array}{l}n=19 \\
\text { Shells }\end{array}$} & \multicolumn{4}{|c|}{ Intershell reproducibility of Mo profiles } & \multicolumn{4}{|c|}{ Molybdenum shell enrichments } \\
\hline & \multicolumn{3}{|c|}{ Correlation coefficients $r$} & \multirow{2}{*}{$\begin{array}{c}\text { Probability } \\
p\end{array}$} & & \multirow[b]{2}{*}{ Date $( \pm 3 \mathrm{~d})$ Mean } & \multicolumn{2}{|c|}{$([\mathrm{Mo}] /[\mathrm{Ca}])_{\text {shell }}$ ratios $(\mu \mathrm{mol} / \mathrm{mol})$} \\
\hline & 1 vs. 2 & 1 vs. 3 & 2 vs. 3 & & & & SD & $\%$ RSD \\
\hline \multirow[t]{2}{*}{$1998(n=3)$} & \multirow[t]{2}{*}{0.89} & \multirow[t]{2}{*}{0.89} & \multirow[t]{2}{*}{0.98} & \multirow[t]{2}{*}{$<10^{-28}$} & peak 1 & 9-Jun & $0.735 \pm 0.288$ & 39 \\
\hline & & & & & peak 2 & 10-Jul & $0.130 \pm 0.071$ & 55 \\
\hline $1999(n=3)$ & 0.95 & 0.72 & 0.52 & $<7.10^{-6}$ & peak 1 & 7-May & $0.194 \pm 0.126$ & 65 \\
\hline $2000(n=3)$ & 0.85 & 0.97 & 0.91 & $<3.10^{-19}$ & peak 1 & 17-May & $1.10 \pm 0.52$ & 47 \\
\hline \multirow[t]{2}{*}{$2001(n=3)$} & \multirow[t]{2}{*}{0.53} & \multirow[t]{2}{*}{0.37} & \multirow[t]{2}{*}{0.99} & \multirow[t]{2}{*}{$<0.004$} & peak 1 & 15-May & $1.53 \pm 0.63$ & 41 \\
\hline & & & & & peak 2 & 21-Jun & $0.037 \pm 0.031$ & 84 \\
\hline \multirow[t]{2}{*}{$2002^{*}(n=2)$} & \multirow[t]{2}{*}{0.88} & \multirow[t]{2}{*}{-} & \multirow[t]{2}{*}{-} & \multirow[t]{2}{*}{$<2.10^{-25}$} & peak 1 & 7-May & $0.126 \pm 0.031$ & 25 \\
\hline & & & & & peak 2 & 4-Jun & $0.072 \pm 0.019$ & 26 \\
\hline \multirow[t]{5}{*}{$2003(n=3)$} & \multirow[t]{5}{*}{0.87} & \multirow[t]{5}{*}{0.90} & \multirow[t]{5}{*}{0.73} & \multirow[t]{5}{*}{$<6.10^{-25}$} & peak 1 & 1-Jun & $1.20 \pm 0.05$ & 4 \\
\hline & & & & & peak 2 & 20-Jul & $0.930 \pm 0.261$ & 28 \\
\hline & & & & & peak 3 & 4-Sep & $0.251 \pm 0.157$ & 63 \\
\hline & & & & & peak 4 & 25-Sep & $0.341 \pm 0.031$ & 9 \\
\hline & & & & & peak 5 & 6-Oct & $0.460 \pm 0.167$ & 36 \\
\hline $2004 *(n=2)$ & 0.46 & - & - & $<0.004$ & peak 1 & 9-May & $0.062 \pm 0.051$ & 83 \\
\hline
\end{tabular}

* For these years, only two shells were analysed.

these maximum $([\mathrm{Mo}] /[\mathrm{Ca}])_{\text {shell }}$ ratios were site- and yeardependent (Table 2). These results strongly suggest that the $\mathrm{Mo} / \mathrm{Ca}$ shell pattern as measured along the North West French coast indicates that the Mo uptake is a reproducible and ubiquitous phenomenon in this species and occurs irrespective of time, population or geographic location.

\subsubsection{Recurrence of $([\mathrm{Mo}] /[\mathrm{Ca}])_{\text {shell }}$ maxima in scallop shells sampled from the Bay of Brest (Brittany) over a 7-year period}

The inter-annual study was carried out over a 7-year period (1998 to 2004) in the Bay of Brest (Roscanvel). As in 2003, an inter-shell comparison of $([\mathrm{Mo}] /[\mathrm{Ca}])_{\text {shell }}$ profiles of $3 \mathrm{ju}-$ venile scallops were performed each year and confirmed the significant reproducibility of $([\mathrm{Mo}] /[\mathrm{Ca}])$ shell profiles $\left(r^{2}>\right.$ 0.37, $p<0.05, n=19$ shells; Table 1). A recurrent pattern was obtained for $([\mathrm{Mo}] /[\mathrm{Ca}])_{\text {shell }}$ profiles, exhibiting a background level under the detection limit and a spring periodic transient maximum of ([Mo]/[Ca] $)_{\text {shell }}$ ratio (May-June) (Table 1, Fig. 3). In 2003, other spring and summer maxima were observed. The usual spring $([\mathrm{Mo}] /[\mathrm{Ca}])_{\text {shell maximum }}$ presented highly variable maximum ratios depending on the year (Table 1). Additional ([Mo]/[Ca] $)_{\text {shell maxima were also }}$ measured in the summer, but usually exhibited much lower intensities.

This 7-year survey demonstrates firstly, the inter-annual recurrence of $([\mathrm{Mo}] /[\mathrm{Ca}])_{\text {shell }}$ profiles with their significant spring-time peaks. Secondly, the maximum $([\mathrm{Mo}] /[\mathrm{Ca}])_{\text {shell }}$ ratio was characterised by its significant reproducibility amongst a single population (3 juvenile scallop shells per year) and its occurrence in spring. Thirdly, the high re-
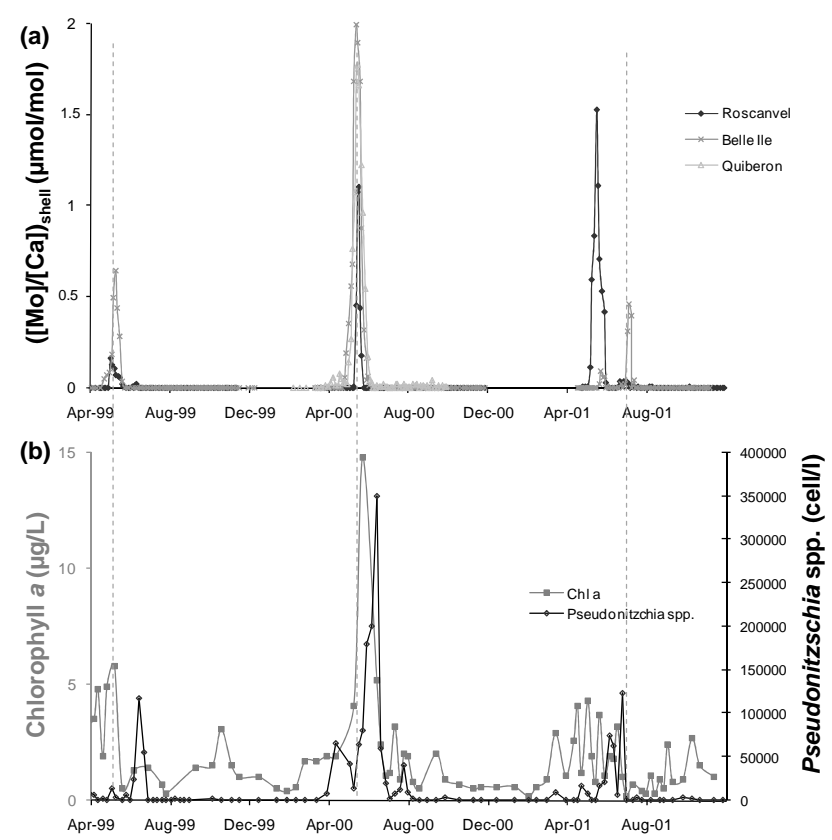

Fig. 2. Comparison of mean $([\mathrm{Mo}] /[\mathrm{Ca}])_{\text {shell }}$ profiles from 1999 to 2001 (a) from 3 sites in Brittany, France to examine the occurrence

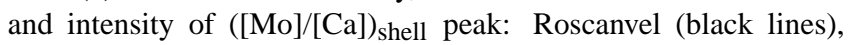
Belle Ile (dark grey lines), Quiberon (light grey lines); and (b) with the phytoplankton concentration (total biomass with chlorophyll $a$, and specific diatom concentration with Pseudonitzschia spp.) monitored at Quiberon station, close to the sampling zone named Quiberon, and the closest monitoring station to the Belle Ile sampling zone. Mean $([\mathrm{Mo}] /[\mathrm{Ca}])_{\text {shell }}$ profiles is the average of 3 shell profiles per year (except in 1999 and 2000 for Belle Ile, $n=4)$. 
Table 2. ([Mo]/[Ca $)_{\text {shell }}$ ratio history in bivalve shells from different coastal temperate ecosystems. Both background, maximum $([\mathrm{Mo}] /[\mathrm{Ca}])_{\text {shell }}$ ratios and $([\mathrm{Mo}] /[\mathrm{Ca}])_{\text {shell }}$ enrichment factors were examined according to the period of $([\mathrm{Mo}] /[\mathrm{Ca}])_{\text {shell }}$ shell enrichments.

\begin{tabular}{lccccc}
\hline $\begin{array}{l}\text { Coastal } \\
\text { temperate } \\
\text { ecosystems }\end{array}$ & $\begin{array}{c}\text { Investigated } \\
\text { period }\end{array}$ & $\begin{array}{c}\text { Background } \\
([\mathrm{Mo}] /[\mathrm{Ca}])_{\text {shell }} \\
\text { ratio }(\mu \mathrm{mol} / \mathrm{mol})\end{array}$ & $\begin{array}{c}([\mathrm{Mo}] /[\mathrm{Ca}])_{\text {shell }} \\
\text { enrichment } \\
\text { periods }\end{array}$ & $\begin{array}{c}\text { Maximum of } \\
([\mathrm{Mo}] /[\mathrm{Ca}])_{\text {shell }} \\
\text { ratio }(\mu \mathrm{mol} / \mathrm{mol})\end{array}$ & $\begin{array}{c}\left(([\mathrm{Mo}] /[\mathrm{Ca}])_{\text {shell }}\right)_{\mathrm{max}} / \\
\left(([\mathrm{Mo}] /[\mathrm{Ca}])_{\mathrm{shel}}\right)_{\mathrm{bkg}}\end{array}$ \\
\hline $\begin{array}{l}\text { Bay of Brest, France } \\
\left(48^{\circ} 20^{\prime} \mathrm{N}, 4^{\circ} 30^{\prime} \mathrm{W}\right)\end{array}$ & $1998-2004$ & $<0.003$ & May to July* & $0.037-1.53$ & $13-562$ \\
$\begin{array}{l}\text { Quiberon, France } \\
\left(47^{\circ} 30^{\prime} \mathrm{N}, 3^{\circ} 00^{\prime} \mathrm{W}\right)\end{array}$ & 2000 & $<0.003$ & May & 1.78 & 654 \\
$\begin{array}{l}\text { Belle Ile, France } \\
\left(47^{\circ} 20^{\prime} \mathrm{N}, 3^{\circ} 10^{\prime} \mathrm{W}\right)\end{array}$ & $1999-2001$ & $<0.003$ & May to July & $0.094-2.00$ & $34-735$ \\
$\begin{array}{l}\text { Bay of Seine, France } \\
\left(49^{\circ} 30^{\prime} \mathrm{N}, 0^{\circ} 30^{\prime} \mathrm{W}\right)\end{array}$ & 2004 & $<0.003$ & May & 0.355 & 131 \\
\hline
\end{tabular}

* supplementary Mo peaks in September-October 2003.
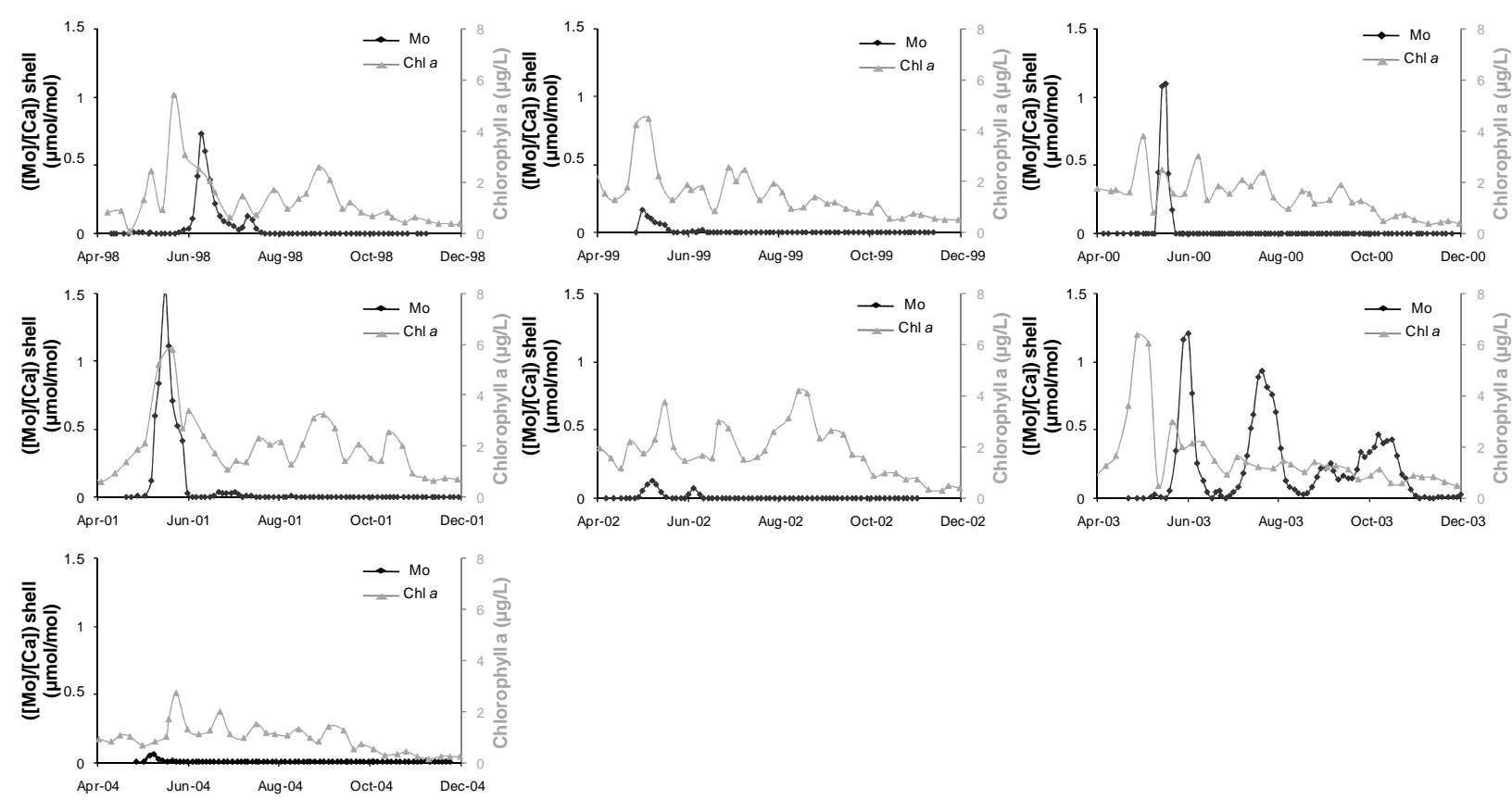

Fig. 3. Mean $([\mathrm{Mo}] /[\mathrm{Ca}])_{\text {shell }}$ profiles in shells $(n=3)$ from Roscanvel over a 7-year period (1998-2004) compared to chlorophyll $a$ ( $\left.\mu \mathrm{g} / \mathrm{L}\right)$ concentrations measured at SOMLIT station in the Bay of Brest $\left(48^{\circ} 21^{\prime} \mathrm{N}, 4^{\circ} 33^{\prime} \mathrm{W}\right)$, nearby the sampling zone (Roscanvel).

producibility of spring $([\mathrm{Mo}] /[\mathrm{Ca}])_{\text {shell }}$ enrichment (intraindividual, inter-annual, inter-site) indicates an environmental control on Mo incorporation within the shells. It is interesting to note that Thébault et al. (2009) highlighted a similar pattern of $([\mathrm{Mo}] /[\mathrm{Ca}])_{\text {shell }}$ ratio in tropical scallops (Comptopallium radula, New Caledonia) showing the global extent of this environmental process.

\subsection{Influence of environmental conditions on the occurrence and the amplitude of the $([\mathrm{Mo}] /[\mathrm{Ca}])_{\text {shell }}$ enrichment}

\subsubsection{Influence of water column biogeochemistry on $([\mathrm{Mo}] /[\mathrm{Ca}])_{\text {shell }}$ enrichment in the Bay of Brest (1998 to 2004)}

The complete environmental database was examined during the 7-year survey (1998-2004) in the Bay of Brest and compared to spring $([\mathrm{Mo}] /[\mathrm{Ca}])_{\text {shell }}$ maxima levels. Profiles 
of $([\mathrm{Mo}] /[\mathrm{Ca}])_{\text {shell }}$ ratio were compared with $\mathrm{Chl} a$ concentrations along the growth period (Fig. 3). This figure underlined, in certain years, $(1999,2001)$ concomitant $([\mathrm{Mo}] /[\mathrm{Ca}])_{\text {shell }}$ and $\mathrm{Chl} a$ maxima. For 3 others years $(1998$, 2000, 2003), a short delay is observed between the Chl $a$ peak and that of the $([\mathrm{Mo}] /[\mathrm{Ca}])_{\text {shell }}$ ratio. For the remaining years investigated $(2002,2004)$, a $([\mathrm{Mo}] /[\mathrm{Ca}])_{\text {shell }}$ maximum precedes the $\mathrm{Chl} a$ peak. It is important to underline that for similar Chl $a$ maxima, ([Mo]/[Ca] $)_{\text {shell }}$ spring maxima exhibit much more variation. This result thus argues against a direct relation with the phytoplankton biomass as measured through the $\mathrm{Chl} a$ content. The increasing concentration of particulate organic carbon (POC) in the water column is also usually associated with maximum $\mathrm{Chl} a$ concentrations and revealed similar variations (Fig. 4). Such as for Chl $a$, the POC content is not directly related to the occurrence and intensity of spring $([\mathrm{Mo}] /[\mathrm{Ca}])_{\text {shell }}$ maxima, even if some of these $([\mathrm{Mo}] /[\mathrm{Ca}])_{\text {shell }}$ maxima matched a preceding or concomitant POC enrichment.

The phytoplankton composition in the weeks preceding the $([\mathrm{Mo}] /[\mathrm{Ca}])_{\text {shell }}$ maximum was always dominated by diatoms (up to 87\%), even in summer 2003. The recurrent and dominant phytoplankton genera (among the hundred considered species) were three diatom genera: Chaetoceros spp., Pseudonitzschia spp. and Rhizosolenia spp. Maxima of $([\mathrm{Mo}] /[\mathrm{Ca}])_{\text {shell }}$ ratio generally occurred before Chaetoceros spp. blooms, and concomitantly with Pseudonitzschia spp. and Rhizosolenia spp. blooms. In summer 2003, $([\mathrm{Mo}] /[\mathrm{Ca}])_{\text {shell }}$ maxima were mainly concomitant with dominant Chaetoceros spp. blooms (except in October). Late $([\mathrm{Mo}] /[\mathrm{Ca}])_{\text {shell }}$ maxima levels might be induced by subsequent atypical phytoplankton blooms, caused by exceptionally warm conditions during summer 2003.

$([\mathrm{Mo}] /[\mathrm{Ca}])_{\text {shell }}$ maximum events usually occurred during a characteristic period of nutrient depletion (late spring). The highest depletion of silicic acid between winter and spring and its further phytoplankton uptake were always related to important maxima of $([\mathrm{Mo}] /[\mathrm{Ca}])_{\text {shell }}$ ratio (Fig. 4d). The comparison of $([\mathrm{Mo}] /[\mathrm{Ca}])_{\text {shell }}$ profiles with Pseudonitzschia spp. and silicic acid concentrations underline decreasing or minimum silicic acid concentration and the occurrence of a Pseudonitzschia spp. bloom which preceded or were concomitant with ([Mo]/[Ca] $)_{\text {shell }}$ maxima (Fig. 4d).

These overall observations suggest that Mo shell uptake is promoted by the significant spring pelagic productivity, which can induce changing conditions at the SWI in the environment surrounding the scallop. The 7-year survey demonstrates however that the $([\mathrm{Mo}] /[\mathrm{Ca}])_{\text {shell }}$ maxima cannot be directly related to specific phytoplankton species.

\subsubsection{Evolution of the Mo partitioning between the shell and the seawater in 2000 (Bay of Brest)}

A specific survey was carried out in 2000. For each $([\mathrm{Mo}] /[\mathrm{Ca}])_{\text {shell }}$ profile, a large array of environmental variables was continuously monitored in the Bay of Brest and regular measurements of dissolved Mo in bottom seawater were compared to demonstrate major biogeochemical features influencing spring $([\mathrm{Mo}] /[\mathrm{Ca}])_{\text {shell }}$ maximum levels. In 2000, Mo dissolved concentrations in seawater exhibited a stable background concentration of $132 \pm 11 \mathrm{nmol} / \mathrm{L}$ punctuated by only one significant 3 -fold maximum the 12 May $(428 \pm 31 \mathrm{nmol} / \mathrm{L})$ (Fig. 5a). This increased concentration of dissolved Mo in bottom waters slightly preceded the ([Mo]/[Ca] $)_{\text {shell }}$ maximum on the 17 May 2000. Assuming an accurate date assignment for the $([\mathrm{Mo}] /[\mathrm{Ca}])_{\text {shell }}$ maximum, this short time lag could be induced by the scallop uptake of Mo before its shell precipitation.

In order to better constrain the conservative or nonconservative behaviour of Mo in the bottom waters of the Bay of Brest (Roscanvel), an evaluation of the "apparent" distribution between the shell and the seawater was performed, first assuming that the particulate phase Mo is not involved. The distribution of Mo between solid carbonate and seawater is expressed by the partition coefficients:

$D_{\mathrm{Mo}}=([\mathrm{Mo}] /[\mathrm{Ca}])_{\text {shell }} /([\mathrm{Mo}] /[\mathrm{Ca}])_{\mathrm{sw}}$

with $[\mathrm{Mo}]$ the Mo concentration and $[\mathrm{Ca}]$ the calcium concentration in shell or in seawater (sw). In 2000, this partition coefficient revealed a background averaging $D_{\mathrm{Mo}}=1.5 \times 10^{-4}$ punctuated by a single dramatic spring increase (maximum $D_{\mathrm{Mo}}=0.081$ ) concomitant with the maximum $([\mathrm{Mo}] /[\mathrm{Ca}])_{\text {shell }}$ level. These results also underline a non-conservative behaviour of dissolved Mo in bottom waters associated with the $([\mathrm{Mo}] /[\mathrm{Ca}])_{\text {shell }}$ maximum levels (i.e. in the carbonate shell matrix). The only known molybdate mineral containing $\mathrm{Ca}$ is powellite $\left(\mathrm{CaMoO}_{4}\right)$ which exhibit a low solubility of $250 \mu \mathrm{mol} / \mathrm{L}$ and a thermodynamic solubility constant of $K s=10^{-7.2}\left(T=298 \mathrm{~K}, P=1.13 \times 10^{-5} \mathrm{~Pa}\right.$, $S=0$ ) (Swinkels et al., 2004). The low background partition coefficient $\left(D_{\mathrm{Mo}}=1.5 \times 10^{-4}\right)$ agrees first with an anionic Mo precipitation pathway within the $\mathrm{CaCO}_{3}$ shell. Second, the dramatic spring maximum partition coefficient, $D_{\mathrm{Mo}}=0.081$, cannot be explained either by any variations of the physicochemical conditions in the seawater (i.e. temperature, salinity, dissolved Mo concentration) or any variations of shell growth physiology (i.e. growth rate measurements). This result suggests that Mo partition coefficient and shell concentrations during the spring enrichment event cannot be described by a direct dissolved Mo uptake. In this particular case, Mo shell uptake from enriched particulate phases must be considered, although no measurements are available in this study. This assumption is also supported by a seasonal non-conservative behaviour of Mo previously observed in coastal North Sea waters off Germany (Dellwig et 


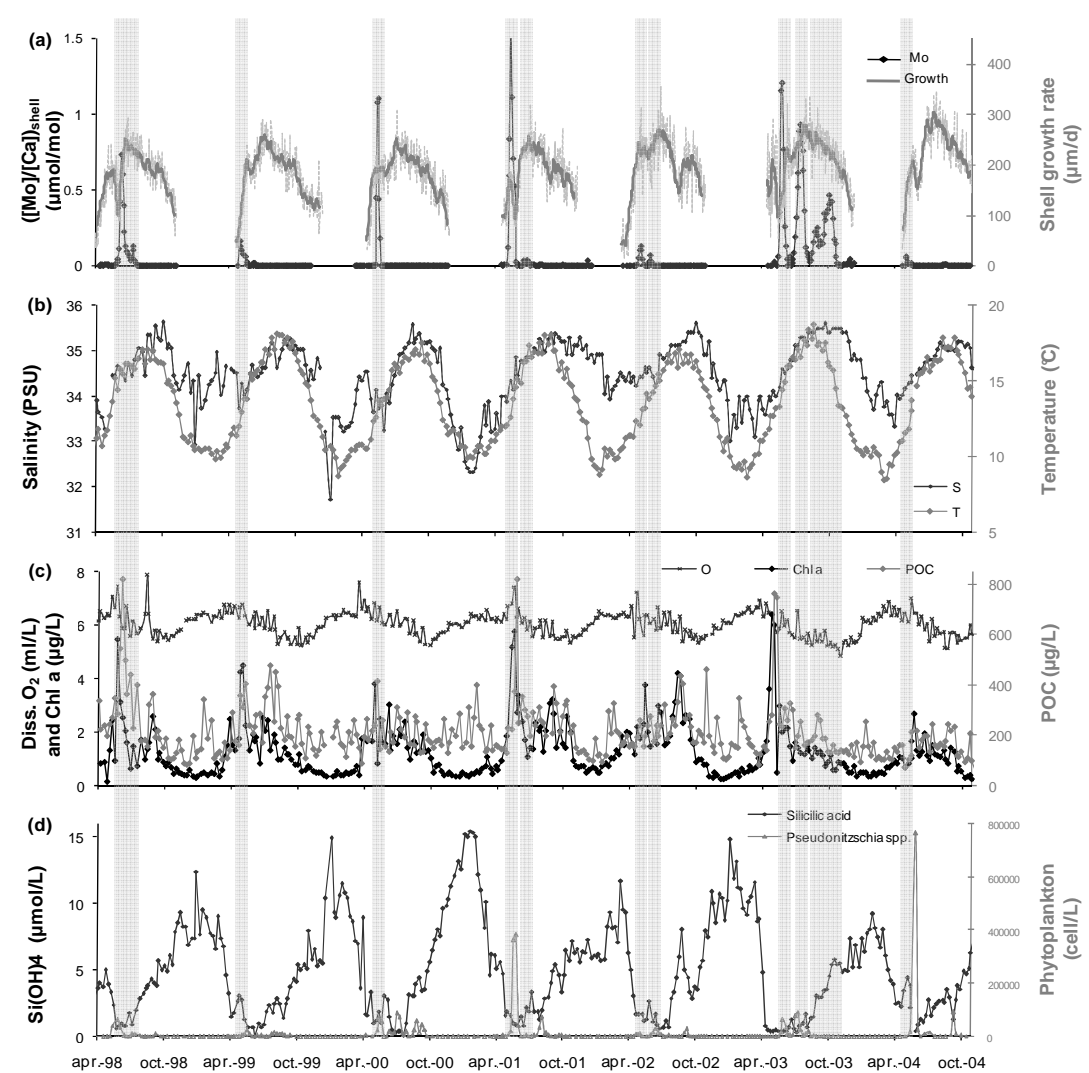

Fig. 4. (a) Mean ([Mo]/[Ca] $)_{\text {shell }}$ concentration profiles $(n=3)$ from Roscanvel over a 7-year period (1998-2004) compared to shell growth rate $(\mu \mathrm{m} / \mathrm{d})$; (b) salinity (PSU) and temperature $\left({ }^{\circ} \mathrm{C}\right)$; (c) dissolved oxygen $(\mathrm{mL} / \mathrm{L})$, chlorophyll $a(\mu \mathrm{g} / \mathrm{L})$ and particulate organic carbon (POC, $\mu \mathrm{g} / \mathrm{L})$; (d) silicic acid concentrations $(\mu \mathrm{mol} / \mathrm{L})$ and Pseudonitzschia spp. concentrations (cell/L) in surface seawater. Environmental monitoring data (weekly resolution) are from SOMLIT station $\left(48^{\circ} 21^{\prime} \mathrm{N}, 4^{\circ} 33^{\prime} \mathrm{W}\right.$ ), except in 2003 and 2004 for diatom levels (Lanvéoc station $\left(48^{\circ} 18^{\prime} \mathrm{N}, 4^{\circ} 27^{\prime} \mathrm{W}\right)$; 15-days resolution), both stations being in the Bay of Brest near the Roscanvel sampling zone.

al., 2007) which exhibits transient enrichment and depletion of Mo concentration in the particulate and dissolved phases, respectively. However, the comparison between that study and our work remains difficult to address considering the distinct experimental objectives, approaches and characteristics of the two ecosystems.

To support a dietary particulate uptake of Mo by the scallop, Mo measurements in soft tissues of Pecten maximus bivalves collected at Roscanvel in January 2003 also revealed the highest Mo concentration in the digestive gland $(167 \pm 63 \mathrm{nmol} / \mathrm{g})$, which represents $69 \%$ of the total Mo in the bivalve (soft tissues and shell included) (Barats, 2006). A study of Mo bioaccumulation in scallop tissues and organs revealed the greatest concentration of Mo in the digestive gland (Bustamante and Miramand, 2005). In addition, Mo in the digestive gland appears to be mostly bound to a soluble fraction (Bustamante and Miramand, 2005). Scallop ingestion of suspended particles would thus provide available dissolved Mo to precipitate in the calcite shell. Both shell uptake of dissolved and particulate Mo can be thus considered to induce maximum $([\mathrm{Mo}] /[\mathrm{Ca}])_{\text {shell }}$ levels.

\subsection{Transient biogeochemical processes potentially associated to spring Mo uptake in the scallop shell}

\subsubsection{Influence of benthic processes on Mo inputs to bottom waters}

Benthic Mo inputs were first examined because of the extended knowledge on benthic processes that lead to the release Mo at the SWI essentially from the reductive dissolution of manganese oxides (Crusius et al., 1996; Crusius and Thomson, 2000; Morford et al., 2001; Chaillou et al., 2002; Dalai et al., 2005; Elbaz-Poulichet et al., 2005; Morford et al., 2005). Because dissolved $\mathrm{Mn}$ is also a good proxy for reductive benthic exchange at the SWI, variations of $([\mathrm{Mn}] /[\mathrm{Ca}])_{\text {shell }}$ ratio in 2000 were thus examined concomitantly with $([\mathrm{Mo}] /[\mathrm{Ca}])_{\text {shell }}$ ratio, dissolved Mo and $\mathrm{Mn}$ (Fig. 5a, b). In addition, ([Mn]/[Ca] $)_{\text {shell }}$ ratio were found to be correlated to both riverine and benthic inputs under reductive summer conditions in the Bay of Seine (Barats et al., 2008). In the Bay of Brest, variations of $([\mathrm{Mn}] /[\mathrm{Ca}])_{\text {shell }}$ ratio in 2000 were slightly decreasing in spring, steady in summer and slightly increasing in autumn (Fig. 5b). In May, 


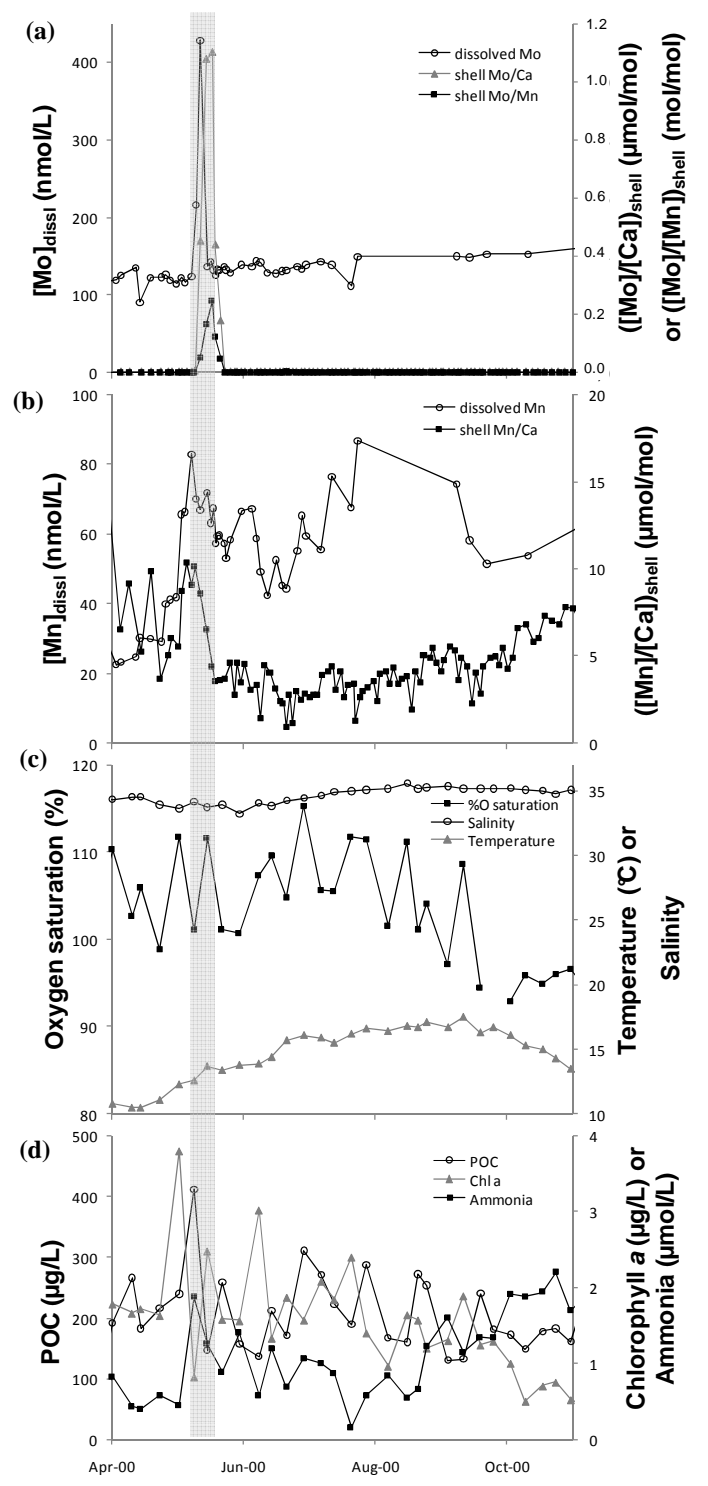

Fig. 5. (a) Mean $([\mathrm{Mo}] /[\mathrm{Ca}])_{\text {shell }}$ and $([\mathrm{Mo}] /[\mathrm{Mn}])_{\text {shell }}$ profiles $(n=3)$ obtained in 2000 in the Bay of Brest and Mo concentrations ( $\mathrm{nmol} / \mathrm{L}$ ) in dissolved seawater (sampled $1 \mathrm{~m}$ above the SWI) compared with (b) mean $([\mathrm{Mn}] /[\mathrm{Ca}])_{\text {shell }}$ profiles and dissolved $\mathrm{Mn}$ concentrations $(\mathrm{nmol} / \mathrm{L})$; (c) seawater temperature $\left({ }^{\circ} \mathrm{C}\right)$, salinity and oxygen saturation (\%); and (d) particulate organic carbon (POC), chlorophyll $a(\mu \mathrm{g} / \mathrm{L})$ and ammonia $(\mu \mathrm{mol} / \mathrm{L})$ concentrations.

dissolved Mn in bottom seawater was not significantly higher than the rest of the year, and the water column was well mixed and oxygenated by the tidal dynamics which argues against reductive conditions (Fig. 5a-c). It is important to mention that the Bay of Brest receives much lower freshwater inputs compared to the Bay of Seine which explain smaller amplitudes of the temporal variations in dissolved $\mathrm{Mn}$ and $([\mathrm{Mn}] /[\mathrm{Ca}])_{\text {shell }}$ ratio (Fig. $\left.5 \mathrm{~b}\right)$. The $([\mathrm{Mo}] /[\mathrm{Ca}])_{\text {shell pattern }}$ was different than the $([\mathrm{Mn}] /[\mathrm{Ca}])_{\text {shell }}$ pattern suggesting a distinct biogeochemical behavior at the SWI. Considering the $([\mathrm{Mo}] /[\mathrm{Ca}])_{\text {shell }}$ profile, variations of $([\mathrm{Mo}] /[\mathrm{Mn}])_{\text {shell }}$ ratio also reveal a steady ratio averaging $700 \mu \mathrm{mol} / \mathrm{mol}$ punctuated by a maximum of $0.250 \mathrm{~mol} / \mathrm{mol}$ (Fig. 5a) demonstrating distinct shell uptake routes for Mo and Mn during the spring Mo enrichment. In the Bay of Brest, benthic inputs from reductive dissolution of Mn oxides are probably not a major source of Mo for the shell. This conclusion is similar to the one suggested by Thébault et al. (2009), but does not preclude that other benthic processes can be involved. Releases of substantial amounts of Mo from organic matter degradation during an algal decay at the SWI were previously suggested to be the best explanation for Mo enrichment in bottom waters (Kunzendorf et al., 2001; Dellwig et al., 2007). The observation in 2000 of increasing $\mathrm{NH}_{4}^{+}$concentrations in seawater concomitantly with higher Mo concentrations in bottom seawater (Fig. 5) also confirm the rapid mineralization of biogenic material settling during the post bloom period (Bally et al., 2004).

\subsubsection{Influence of a biogenic pelagic process on Mo inputs to bottom waters}

The Mo input in bottom waters is assumed to be induced by pelagic biogenic processes in May 2000 as the phytoplankton concentration was increasing. Chl $a$ and POC concentrations displayed two maximum concentrations (respectively, 2 and 15 May) with the highest maximum on 2 May ([Chl $a]=3.8 \mu \mathrm{g} / \mathrm{L}$ and $[\mathrm{POC}]=412 \mu \mathrm{g} / \mathrm{L}$ ) (Fig. 5d). The variations of $([\mathrm{Mo}] /[\mathrm{Ca}])_{\text {shell }}$ ratios exhibit a peak 15 days after the first maximum Chl $a$ and POC concentrations, characterizing the most intense spring phytoplankton bloom. The second maximum of Chl $a$ and POC occurred after the spring maximum $([\mathrm{Mo}] /[\mathrm{Ca}])_{\text {shell }}$ ratio, showing no influence on the $([\mathrm{Mo}] /[\mathrm{Ca}])_{\text {shell }}$ ratio. The pelagic biogenic process influencing the $([\mathrm{Mo}] /[\mathrm{Ca}])_{\text {shell }}$ maxima is thus specific to the spring post-bloom period. In 2000, nutrient dynamics over this productive period was previously described at the SOMLIT site (Ragueneau et al., 2002), which demonstrate that the large nutrient loads in spring is followed by a phytoplankton bloom dominated by diatoms (up to 94\%). The dominant phytoplankton genera were Skeletonema costatum spp., Chaetoceros spp., Pseudonitzschia spp. and Rhizosolenia spp. To explain $([\mathrm{Mo}] /[\mathrm{Ca}])_{\text {shell }}$ maxima in the shell of the tropical bivalve Comptopallium radula, Thébault et al. (2009) suggested the ingestion of $\mathrm{N}_{2}$-fixing cyanobacteria. The dominant marine $\mathrm{N}_{2}$-fixing cyanobacteria are Trichodesnium spp. and Richelia intracelllularis (Sellner, 1997). Trichodesmium spp. blooms do not occur because the seawater temperature in spring is too low $\left(<21^{\circ} \mathrm{C}\right)$. Richelia intracellularis is a small cyanobacterium living in endosymbiotic association within some diatom genera such as Rhizosolenia and Chaetoceros, which are dominant during spring in the Bay of Brest. This association of $R$. intracellularis as an endosymbiont in Rhizosolenia or Chaetoceros diatoms usually occurs in warm tropical seawater (Gomez et al., 2005), 
and is specific to nitrate depleted ecosystems such as the Baltic Sea or the North Atlantic Ocean, and rarely observed in coastal temperate environment (Sellner, 1997; Villareal, 1992). In the Bay of Brest, no other specific pathway explaining Mo enrichment within phytoplankton can be established during the productive period of the year. This statement also agrees with the Mo concentration in phytoplankton cell data obtained from experimental culture on various genera and species which did not show Mo cell enrichment under controlled growing conditions (Ho et al., 2003; Quigg et al., 2003). Mo cell enrichment would however, be induced by environmental and physiological conditions such as light limitation (Finkel et al., 2006) or nitrate utilization (Thébault et al., 2009). This last hypothetic process could be conclusive for the Bay of Brest exhibiting significant nitrate inputs from human activities (Ragueneau et al., 2002).

\subsubsection{Influence of diatom productivity on Mo inputs to bottom waters}

([Mo]/[Ca] $)_{\text {shell }}$ peak levels were usually recorded from May to July and correspond to the first major phytoplankton bloom period occurring in the water column of temperate coastal environments. This first major phytoplankton bloom is dominated by diatom species. Scallop Mo uptake and its spring enrichment may thus be related to diatom productivity. Until now, none of these diatom species have been recognized to have an effect on Mo biogeochemistry in the marine environment. Statistical data analyses were performed, using the data from the 7-year survey (1998-2004) in the Bay of Brest, to highlight the parameters potentially related to the amplitude of $([\mathrm{Mo}] /[\mathrm{Ca}])_{\text {shell }}$ maxima over a two week integration period (i.e. from one week before to one week after the dated occurrence of a $([\mathrm{Mo}] /[\mathrm{Ca}])_{\text {shell }} \max$ imum). Bravais Pearson tests revealed only two significant correlations between the amplitude of $([\mathrm{Mo}] /[\mathrm{Ca}])_{\text {shell }}$ maxima and the maximum concentration of Pseudonitzschia spp. $\left(r^{2}=0.53, p<0.05, n=14\right)$ or with the maximum concentration of Chl $a\left(r^{2}<0.32, p<0.05, n=14\right)$. Multiple regression analyses also underlined a relevant relationship expressing the amplitude of maximum $([\mathrm{Mo}] /[\mathrm{Ca}])_{\text {shell }}$ ratios $(\mu \mathrm{mol} / \mathrm{mol})$ according to the maximum relative abundance of Pseudonitzschia spp. (\%) and the maximum concentration of silicic acid $(\mu \mathrm{mol} / \mathrm{L})$ in the seawater $\left(r^{2}=0.40\right.$, $p<0.05, n=14$ ), these two parameters are not significantly correlated. The significance of the regression was improved removing unusual and late $([\mathrm{Mo}] /[\mathrm{Ca}])_{\text {shell }}$ maximum levels in 2003 (peak 3, 4 and 5) $\left(r^{2}=0.88, p<0.05, n=11\right.$ and $\left.d_{\text {cook }}<1\right)$ :

$$
\begin{aligned}
([\mathrm{Mo}] /[\mathrm{Ca}])_{\text {shell }} & =0.877+0.0261(\% \text { Pseudonitzschia } \mathrm{spp} .) \\
& -0.358[\mathrm{Si}] .
\end{aligned}
$$

This relationship exhibited a negative coefficient with silicic acids and a positive one with Pseudonitzschia spp. This can be explained by the fact that silicic acids are actively taken up

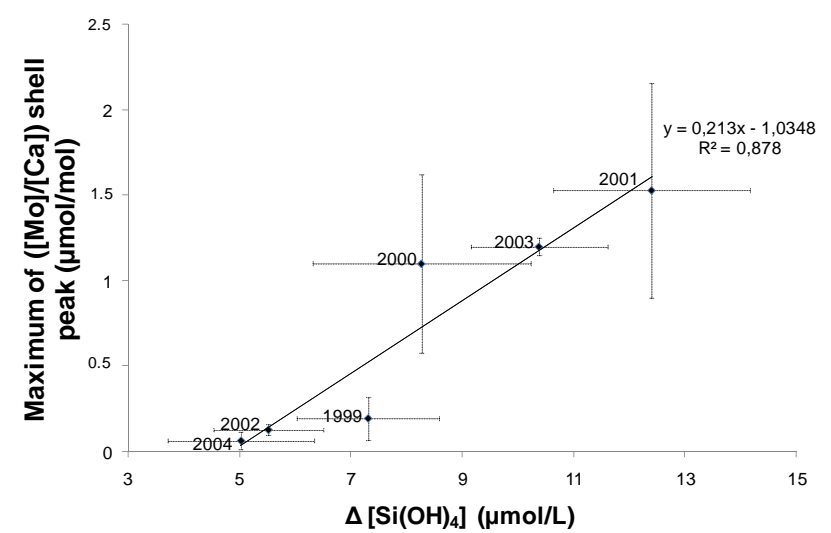

Fig. 6. Relationship between maximum intensity of spring $([\mathrm{Mo}] /[\mathrm{Ca}])_{\text {shell peak }}(\mu \mathrm{mol} / \mathrm{mol})$ and the difference of average silicic acid concentration ( $\mu \mathrm{mol} / \mathrm{L}$ ) between winter (January and February) and spring (May and June), i.e. a delta silicic concentration. The error bars represent the standard deviations on the average $([\mathrm{Mo}] /[\mathrm{Ca}])_{\text {shell }}$ maximum and on the average $\Delta\left[\mathrm{Si}(\mathrm{OH})_{4}\right]$.

by diatoms (Ragueneau et al., 2002) and that Pseudonitzschia spp. blooms usually occur during low or depleted silicic acid concentrations in seawater (Gomez et al., 2007; Pan et al., 1998; Parsons and Dortch, 2002; Prego et al., 2007). Like silicic acids, nitrates are actively taken up by diatoms (Ragueneau et al., 2002). To further establish the underlying association between diatom productivity and Mo enrichment in the scallop shell, the apparent amount of silicic acid or nitrate uptake by diatoms (i.e. "apparent" diatom spring productivity) have been evaluated. This includes subtracting the average minimum concentration measured in late spring ( $n=9$, May and June), compared to the average maximum one observed in winter $(n=11$, December to February). As expected from our previous observations, these "apparent" spring nutrient depletions were significantly correlated to the maximum $([\mathrm{Mo}] /[\mathrm{Ca}])_{\text {shell }}$ ratio both for silicic acid $\left(r^{2}=0.878, p<0.05, n=6\right.$, Fig. 6$)$ and for nitrates $\left(r^{2}=0.780, p<0.05, n=6\right)$. These results indicate also that the maximum $([\mathrm{Mo}] /[\mathrm{Ca}])_{\text {shell }}$ ratios were not directly related to instantaneous total biomass but rather to a post-bloom period. This period is characterised by silicic acid or nitrate depletion and Pseudonitzschia spp. dominance, subsequent to the major diatom production integrated over the spring growth season. Mo inputs at the SWI can thus be induced by a diatom biogenic material downward flux. Diatoms are the sole marine phytoplankton taking up $\mathrm{Si}$ and are characterized by large cell size and density (Sarthou et al., 2005). Mo enrichment in bottom waters may therefore be driven by such biogenic material flux to the SWI. Spring $([\mathrm{Mo}] /[\mathrm{Ca}])_{\text {shell }}$ enrichments are thus supposed to follow scallop uptake of Mo at the SWI. The scallop ingestion of phytoplankton cells nutrified by $\mathrm{NO}_{3}^{-}$(such as diatoms containing high levels of Mo for the activity of nitrate reductase), or the ingestion 
of significant amounts of resuspended microphytobenthos cells nutrified on $\mathrm{NO}_{3}^{-}$was previously proposed to explain $([\mathrm{Mo}] /[\mathrm{Ca}])_{\text {shell }}$ maxima (Thébault et al., 2009). Our data may support these assumptions, but none of these pathways can be completely demonstrated. The processes governing Mo scavenging by biogenic particles and its further uptake by the scallop remain to be elucidated.

\section{Conclusions}

An original investigation of $([\mathrm{Mo}] /[\mathrm{Ca}])_{\text {shell }}$ ratio in bivalves from temperate environments is reported for the first time. The approach uses $([\mathrm{Mo}] /[\mathrm{Ca}])_{\text {shell }}$ profiles along the growth period of the shell and these were determined for several scallops from a same population and during a 7-year period (1998-2004) in temperate coastal ecosystems. These profiles exhibit similar features showing a background concentration $(<2.7 \mathrm{nmol} / \mathrm{mol})$ punctuated by a transient maximum in spring (May to June). This study reveals a new evidence of the non-conservative behaviour of the Mo in coastal waters, and demonstrates the specific Mo enrichment in the surrounding shell habitat during spring-time. The extent of spring $([\mathrm{Mo}] /[\mathrm{Ca}])_{\text {shell }}$ enrichments were explained by the net uptake of silicate and nitrate, suggesting a connection with diatoms' spring-time productivity. The use of Mo records in Pecten maximus shells may further serve as a new proxy for biomonitoring studies in temperate coastal environments which can be extended for other marine biogenic carbonates.

Acknowledgements. This work was supported in the framework of two research programmes: ACI PECTEN (French Ministère de la Recherche) and "Suivi Erika" (INERIS, French Ministère de l'Environnement). Thermo Electron Company is thanked for the loan of the ICP-MS. A. B. acknowledges the Aquitaine Region (ORQUE project) for her Doctoral fellowship. The authors are grateful to Anne Lorrain from the IRD (Brest, France) for the regular scientific SCUBA diving in 2000, Thomas Church (School of Marine Science and Policy, Univ. of Delaware, USA) for linguistic and scientific comments to this manuscript, and Gérard Sinquin (Groupe de Microscopie Electronique, Univ. de Bretagne Occidentale, France) for his help concerning the MEB photographies.

Edited by: J. Middelburg

\section{References}

Adelson, J. M., Heltz, G. R., and Miller, C. V.: Reconstructing the rise of recent coastal anoxia: molybdenum in Chesapeake Bay sediments, Geochim. Cosmochim. Acta, 65, 237-252, 2001.

Bally, G., Mesnage, V., Deloffre, J., Clarisse, O., Lafite, R., and Dupont, J.-P.: Chemical characterization of porewaters in an intertidal mudflat of the Seine estuary: relationship to erosiondeposition cycles, Mar. Pollut. Bull., 49, 163-173, 2004.
Barats, A.: Micro analyse quantitative des éléments traces dans la calcite de la coquille Saint Jacques Pecten maximus par Ablation Laser et Spectrométrie de Masse à Plasma Inductif Couplé (LAICP-MS): une archive journalière de la biogéochimie des environnements côtiers tempérés, Laboratoire de Chimie Analytique Bio Inorganique et Environnement, Université de Pau et des Pays de l'Adour, Pau, France, 301 pp., 2006.

Barats, A., Pécheyran, C., Amouroux, D., Dubascoux, S., Chauvaud, L., and Donard, O. F. X.: Matrix-matched quantitative trace element analysis in calcium carbonate shells by Laser Ablation ICP-MS: application to the determination of daily scale profiles in scallop shell (Pecten maximus), Anal. Bioanal. Chem., 387, 1131-1140, 2007.

Barats, A., Amouroux, D., Pécheyran, C., Chauvaud, L., and Donard, O. F. X.: High-frequency archives of manganese inputs to coastal waters (Bay of Seine, France) resolved by the LA-ICPMS analysis of calcitic growth layers along scallop shells (Pecten maximus), Environ. Sci. Technol., 42, 86-92, 2008.

Barats, A., Amouroux, D., Chauvaud, L., Pécheyran, C., Lorrain, A., Thèbault, J., Church, T. M., and Donard, O. F. X.: High frequency Barium profiles in shells of the Great Scallop Pecten maximus: a methodical long-term and multi-site survey in Western Europe, Biogeosciences, 6, 157-170, 2009, http://www.biogeosciences.net/6/157/2009/.

Bustamante, P. and Miramand, P.: Subcellular and body distributions of 17 trace elements in the variegated scallop Chlamys varia from the French coast of the Bay of Biscay, Sci. Total Environ., 337, 59-73, 2005.

Chaillou, G., Anschutz, P., Lavaux, G., Schafer, J., and Blanc, G.: The distribution of Mo, $\mathrm{U}$, and $\mathrm{Cd}$ in relation to major redox species in muddy sediment of the Bay of Biscay, Marine Chem., 80, 41-59, 2002.

Chauvaud, L.: La coquille Saint Jacques en rade de Brest: un modèle biologique d'étude des réponses de la faune benthique aux fluctuations de l'environnement., Université de Bretagne Occidentale, Brest, France, 1998.

Chauvaud, L., Thouzeau, G., and Paulet, Y. M.: Effects of environmental factors on the daily growth rate of Pecten maximus juveniles in the Bay of Brest (France), J. Exp. Mar. Biol. Ecol., 227, 83-111, 1998.

Chauvaud, L., Lorrain, A., Dunbar, R. D., Paulet, Y. M., Thouzeau, G., Jean, F., Guarini, J.-M., and Mucciarone, D.: Shell of the Great Scallop Pecten maximus as a high-frequency archive of paleoenvironmental changes, Geochem. Geophy. Geosy., 6, 1-15, 2005.

Cole, J. J., Lane, J. M., Marino, R., and Howarth, R. W.: Molybdenum assimilation by cyanobacteria and phytoplankton in freshwater and salt water, Limnol. Oceanogr., 38, 25-35, 1993.

Collier, R. W.: Molybdenum in the Northeast Pacific Ocean, Limnol. Oceanogr., 30, 1351-1354, 1985.

Crusius, J., Calvert, S., Pedersen, T., and Sage, D.: Rhenium and molybdenum enrichments in sediments as indicators of oxic, suboxic and sulfidic conditions of deposition, Earth Planet. Sci. Lett., 145, 65-78, 1996.

Crusius, J. and Thomson, J.: Comparative behavior of authigenic $\mathrm{Re}, \mathrm{U}$, Mo during reoxidation and subsequent long-term burial in marine sediments, Geochim. Cosmochim. Acta, 64, 2233-2242, 2000.

Dalai, T. K., Nishimura, K., and Nozaki, Y.: Geochemistry of 
molybdenum in the Chao Phraya River estuary, Thailand: Role of suboxic diagenesis and porewater transport, Chem. Geol., 218, 189-202, doi:110.1016/j.chemgeo.2005.1001.1002, 2005.

Dellwig, O., Beck, M., Lemke, A., Lunau, M., Kolditz, K., Schnetger, B., and Brumsack, H.-J.: Non-conservative behaviour of molybdenum in coastal waters: Coupling geochemical, biological, and sedimentological processes, Geochim. Cosmochim. Acta, 71, 2745-2761, 2007.

Dodd, J. R.: Environmental control of strontium and magnesium in Mytilus, Geochim. Cosmochim. Acta, 29, 385-398, 1965.

Elbaz-Poulichet, F., Seidel, J. L., Jezequel, D., Metzger, E., Prevot, F., Simonucci, C., Sarazin, G., Viollier, E., Etcheber, H., and Jouanneau, J.-M.: Sedimentary record of redox-sensitive elements (U, Mn, Mo) in a transitory anoxic basin (the Thau lagoon, France), Marine Chem., 95, 271-281, 2005.

Erickson, B. E. and Heltz, G. R.: Molybdenum (VI) speciation in sulfidic waters: Stability and lability of thiomolybdates, Geochim. Cosmochim. Acta, 64, 1149-1158, 2000.

Finkel, Z. V., Quigg, A., Raven, J. A., Reinfelder, J. R., Schofield, O. E., and Falkowski, P. G.: Irradiance and the elemental stoichiometry of marine phytoplankton, Limnol. Oceanogr., 51, 2690-2701, 2006.

Freitas, P., Clarke, L. J., Kennedy, H., Richardson, C., and Abrantes, F.: $\mathrm{Mg} / \mathrm{Ca}, \mathrm{Sr} / \mathrm{Ca}$, and stable-isotope $(\delta 18 \mathrm{O}$ and $\delta 13 \mathrm{C})$ ratio profiles from the fan mussel Pinna nobilis: Seasonal records and temperature relationships, Geochem. Geophy. Geosy., 6, Q04D14, doi:10.1029/2004GC000872, 2005.

Freitas, P. S., Clarke, L. J., Kennedy, H., Richardson, C. A., and Abrantes, F.: Environmental and biological controls on elemental $(\mathrm{Mg} / \mathrm{Ca}, \mathrm{Sr} / \mathrm{Ca}$ and $\mathrm{Mn} / \mathrm{Ca}$ ) ratios in shells of the king scallop Pecten maximus, Geochim. Cosmochim. Acta, 70, 5119-5133, 2006.

Gillikin, D. P., De Ridder, F., Ulens, H., Elskens, M., Keppens, E., Baeyens, W., and Dehairs, F.: Assessing the reproducibility and reliability of estuarine bivalve shells (Saxidomus giganteus) for sea surface temperature reconstruction: Implications for paleoclimate studies, Palaeogeogr. Palaeocl., 228, 70-85, 2005.

Gillikin, D. P., Lorrain, A., Paulet, Y. M., André, L., and Dehairs, F.: Synchronous barium peaks in high-resolution profiles of calcite and aragonite marine bivalve shells, Geo-Mar. Lett., 28, 351358, 2008.

Giusti, L., Williamson, A. C., and Mistry, A.: Biologically available trace metals in Mytilus edulis from the coast of Northeast England, Environ. Int., 25, 969-981, 1999.

Gomez, F., Furuya, K., and Takeda, S.: Distribution of the cyanobacterium Richelia intracellularis as an epiphyte of the diatom Chaetoceros compressus in the western Pacific Ocean, J. Plankton Res., 27, 323-330, 2005.

Gómez, F., Claustre, H., Raimbault, P., and Souissi, S.: Two HighNutrient Low-Chlorophyll phytoplankton assemblages: the tropical central Pacific and the offshore Per-Chile Current, Biogeosciences, 4, 1101-1113, 2007, http://www.biogeosciences.net/4/1101/2007/.

Hille, R.: Molybdenum and tungsten in biology, TRENDS in Biochemical Sciences, 27, 360-367, 2002.

Ho, T. Y., Quigg, A., Finkel, Z. V., Milligan, A. J., Wyman, K., Falkowski, P. G., and Morel, F. M. M.: The elemental composition of some marine phytoplankton, J. Phycol., 39, 1145-1159, 2003.
Klein, R. T., Lohmann, K. C., and Thayer, C. W.: Bivalve skeletons record sea-surface temperature and delta $\mathrm{O}-18$ via $\mathrm{Mg} / \mathrm{Ca}$ and O-18/O-16 ratios, Geology, 24, 415-418, 1996a.

Klein, R. T., Lohmann, K. C., and Thayer, C. W.: Sr/Ca and ${ }^{13} \mathrm{C} /{ }^{12} \mathrm{C}$ ratios in skeletal calcite of Mytilus trossulus: Covariation with metabolic rate, salinity, and carbon isotopic composition of seawater, Geochim. Cosmochim. Acta, 60, 4207-4221, $1996 b$.

Kunzendorf, H., Voss, M., Brener, W., Andren, T., and Vallus, H.: Molybdenum in sediments of the central Baltic Sea as an indicator for algal blooms, Baltica, 14, 123-130, 2001.

Lazareth, C. E., Van Der Putten, E., André, L., and Dehairs, F.: High-resolution trace element profiles in shells of the mangrove bivalves Isognomon ephippium: a record of environmental spatio-temporal variations, Estuarine, Coast. Shelf Sci., 57, 1103-1114, 2003.

Lorens, R. B. and Bender, M. L.: The impact of solution chemistry on Mytilus edulis calcite and aragonite, Geochim. Cosmochim. Acta, 44, 1265-1278, 1980.

Lorrain, A., Paulet, Y. M., Chauvaud, L., Savoye, N., Nezan, E., and Guerin, L.: Growth anomalies in Pecten maximus from coastal waters (Bay of Brest, France): relationship with diatoms blooms, Journal of Marine Biological Association of the United Kingdom, 80, 667-673, 2000.

Lorrain, A., Gillikin, D. P., Paulet, Y.-M., Chauvaud, L., Le Mercier, A., Navez, J., and André, L.: Strong kinetic effects on $\mathrm{Sr} / \mathrm{Ca}$ ratios in the calcitic bivalve Pecten maximus, Geology, 33, 965968, 2005.

Marino, R., Howarth, R. W., Shamess, J., and Prepas, E.: Molybdenum and sulfate as controls on the abundance of nitrogen-fixing cyanobacteria in saline lakes in Alberta, Limnol. Oceanogr., 35, 245-259, 1990.

Morford, J. L., Russel, A. D., and Emerson, S.: Trace metal evidence for changes in the redox environment associated with the transition from terrigenous clay to diatomaceous, Mar. Geol., 174, 355-369, 2001.

Morford, J. L., Emerson, S. R., Breckel, E. J., and Kim, S. H.: Diagenesis of oxyanions ( $\mathrm{V}, \mathrm{U}, \mathrm{Re}$, and $\mathrm{Mo}$ ) in pore waters and sediments from a continental margin, Geochim. Cosmochim. Acta, 69, 5021-5032, 2005.

Owen, R., Kennedy, H., and Richardson, C.: Experimental investigation into partitioning of stable isotopes between scallop (Pecten maximus) shell calcite and sea water, Palaeogeogr. Palaeocl., 185, 163-174, 2002a.

Owen, R., Kennedy, H., and Richardson, C.: Isotopic partitioning between scallop shell calcite and seawater: effect of shell growth rate, Geochim. Cosmochim. Acta, 66, 1727-1737, 2002b.

Pan, Y., Bates, S. S., and Cembella, A. D.: Environmental stress and domoic acid production by Pseudo-nitzschia: A physiological perspective, Natural Toxins, 6, 127-135, 1998.

Parsons, M. L. and Dortch, Q.: Sedimentological evidence of an increase in Pseudo-nitzschia (Bacillariophyceae) abundance in response to coastal eutrophication, Limnol. Oceanogr., 47, 551558, 2002.

Prego, R., Guzman-Zuniga, D., Varela, M., deCastro, M., and Gomez-Gesteira, M.: Consequences of winter upwelling events on biogeochemical and phytoplankton patterns in a western Galician ria (NW Iberian peninsula), Estuarine, Coast. Shelf Sci., 73, 409-422, 2007. 
Puente, X., Villares, R., Carral, E., and Carballeira, A.: Nacreous shell of Mytilus galloprovincialis as a biomonitor of heavy metal pollution in Galiza (NW Spain), Sci. Total Environ., 183, 205211, 1996.

Quigg, A., Finkel, Z. V., Irwin, A. J., Rosenthal, Y., Ho, T. Y., Reinfelder, J. R., Schofield, O., Morel, F. M. M., and Falkowski, P. G.: The evolutionary inheritance of elemental stoichiometry in marine phytoplankton, Nature, 425, 291-294, 2003.

Ragueneau, O., Chauvaud, L., Leynaert, A., Thouzeau, G., Paulet, Y. M., Bonnet, S., Lorrain, A., Grall, J., Corvaisier, R., Le Hir, M., Jean, F., and Clavier, J.: Direct evidence of a biologically active coastal silicate pump: Ecological implications, Limnol. Oceanogr., 47, 1849-1854, 2002.

Richard, M.: Analyse de la composition élémentaire de Pecten maximus par HR-ICPMS Element2: développements méthodologiques et interprétations écologiques, Doctoral thesis, Institut Universitaire Européen de la Mer, Université de Bretagne Occidentale, Brest, 237 pp., 2009.

Richardson, C. A., Chenery, S. R. N., and Cook, J. M.: Assessing the history of trace metal $(\mathrm{Cu}, \mathrm{Zn}, \mathrm{Pb})$ contamination in the North sea through laser ablation ICP-MS of horse mussel Modiolus modiolus shells, Mar. Ecol. Prog. Ser., 211, 157-167, 2001.

Sarthou, G., Timmermans, K. R., Blain, S., and Treguer, P.: Growth physiology and fate of diatoms in the ocean: a review, J. Sea Res., 53, 25-42, 2005.

Sellner, K. G.: Physiology, ecology, and toxic properties of marine cyanobacteria blooms, Limnol. Oceanogr., 42, 1089-1104, 1997.

Stecher, H. A., Krantz, D. E., Lord III, J. C., Luther III, G. W., and Bock, K. W.: Profiles of strontium and barium in Mercenaria mercenaria and Spisula solidissima, Geochim. Cosmochim. Acta, 60, 3445-3456, 1996.
Sundby, B., Martinez, P., and Gobeil, C.: Comparative geochemistry of cadnium, rhenium, uranium, and molybdenum in continental margin sediments, Geochim. Cosmochim. Acta, 68, 2485-2493, 2004.

Swinkels, P. L. J., Van Der Weijden, R. D., Ajah, A. N., Arifin, Y., Loe, H. L., Manik, M. H., Siriski, I., and Reuter, M. A.: Conceptual process design as a prerequisite for solving environmental problems; a case study of molybdenum removal and recovery from wastewater, Minerals Eng., 17, 205-215, 2004.

Thébault, J., Chauvaud, L., L'Helguen, S., Clavier, J., Barats, A., Jacquet, S., Pécheyran, C., and Amouroux, D.: Barium and molybdenum records in bivalve shells: geochemical proxies for phytoplankton dynamics in coastal environments?, Limnol Oceanogr., 54, 1002-1014, 2009.

Tribovillard, N., Riboulleau, A., Lyons, T., and Baudin, F.: Enhanced trapping of molybdenum by sulfurized marine organic matter of marine origin in Mesozoic limestone and shales, Chem. Geol., 213, 385-401, 2004.

Tuit, C. B. and Ravizza, G.: The marine distribution of molybdenum, Geochim. Cosmochim. Acta, 67, Suppl. 1, p. A495, 2003.

Vander Putten, E., Dehairs, F., Keppens, E., and Baeyens, W.: High resolution distribution of trace elements in the calcite shell layer of modern Mytilus edulis: Environmental and biological controls, Geochim. Cosmochim. Acta, 64, 997-1011, 2000.

Villareal, T. A.: Marine nitrogen-fixing diatom-cyanobacteria symbioses, in: Marine pelagic cyanobacteria: Trichodesnium and others diazotrophs, edited by: Carpenter, E. J., Capone, D. G., and Rueter, J. G., Kluwer Academic Publisher, 163-175, 1992.

Zheng, Y., Anderson, R. F., Van Geen, A., and Kuwabara, J.: Authigenic molybdenum formation in marine sediments: A link to pore water sulfide in the Santa Barbara Basin, Geochim. Cosmochim. Acta, 64, 4165-4178, 2000. 